\title{
Safety Comparison of Over the Counter Bleaching with Professionally Prescribed Home Bleaching Agent
}

\author{
Japsimretjit Kaur Manjit Singh, Masturah Sengut, Mohamad Syahrizal Halim, Zuryati Ab-Ghani, Normastura Abd Rahman \\ Department of Conservative Dentistry, School of Dental Sciences, Universiti Sains Malaysia, Kota Bharu, Kelantan, Malaysia
}

\section{Abstract}

\begin{abstract}
Aims: This aimed to compare the colour changes, microhardness, and surface roughness of the human natural tooth after bleaching treatment with a professional home bleaching agent and over-the-counter (OTC) bleaching agent. Settings and Design: This was an in vitro study using extracted human teeth stained with human blood as specimens. Materials and Methods: Fifty-seven human natural teeth were embedded in acrylic of $2.5 \mathrm{~mm}$ thickness and $14 \mathrm{~mm} \times 8 \mathrm{~mm}$ surface area. The samples were stained with human blood before they were divided into three groups ( $n=19$ per group) of control (C), Professional Bleaching Opalescence PF 15\% (PB), and OTC Whitelight Tooth Whitening set (WL) before being treated with the respective bleaching agents for 10 days. Color changes were measured as colorimetric measurements ( $\mathrm{L}^{*}, \mathrm{a}^{*}$, and $\mathrm{b}^{*}$ values) were recorded during prestaining, poststaining, and postbleaching, while microhardness and surface roughness measurements were recorded for pre- and postbleaching. Statistical Analysis: Statistical analysis was done with SPSS (IBM Statistic, California, USA) version 22.0. Paired $t$-test and nonparametric analysis (Wilcoxon Signed-Rank Test) were used to analyze the data. $P$ value was set as significant at $P<0.05$. Results: The color changes in PB group was not significantly better compared with WL group (PB: 12.2 [4.07] and WL: 12.2 [4.32]). Whereas significant difference was noticed in microhardness after bleaching in PB group with a higher VHN number (500.4 [121.10]) compared with WL group (471.0 [114.47]). The surface roughness (Ra) remain the same for all experimental groups. Conclusions: Both professional home bleaching agent and OTC bleaching agents showed similar efficacy, with no effect on surface roughness, and both caused an increase in microhardness.
\end{abstract}

Keywords: Home bleaching, over the counter bleaching, professionally prescribed home bleaching

\section{INTRODUCTION}

Tooth discolouration is a resultant of varied and complex causes that are either intrinsic or extrinsic in nature. ${ }^{[1]}$ There is a wide range of cosmetic problems arising from tooth discolouration which has led to the public striving for a more esthetically pleasing and presentable appearance. ${ }^{[2]}$ Tooth bleaching procedures have become increasingly popular worldwide $^{[3]}$ as it is an effective and noninvasive treatment if compared to other treatments such as veneer placement and full coverage indirect restorations. ${ }^{[4-6]}$

The three rudimentary approaches for bleaching vital teeth include in-office or power bleaching, at-home or dentist supervised nightguard bleaching, and bleaching with over-the-counter (OTC) products. ${ }^{[7]}$ OTC bleaching method is gaining attention in the market lately because it can be used without the dentist's supervision. It is simpler, less expensive,

\begin{tabular}{|l|l|}
\hline \multicolumn{2}{|c|}{ Access this article online } \\
\hline Quick Response Code: & Website: \\
\hline & www.ejgd.org \\
\cline { 2 - 2 } & \\
\hline
\end{tabular}

less complicated, and requires less in-office time.${ }^{[8]}$ However, there are concerns over its safety and efficacy besides the potential abuse of the products by the public since it is easily available to them. ${ }^{[8]}$ The people tend to overlook the importance of consulting professional advice on tooth bleaching. In fact, the efficacy of OTC bleaching agents remains a question as there is a lack of clinical trials that are able to provide substantial scientific background regarding these bleaching products. ${ }^{[9]}$

Address for correspondence: Dr. Mohamad Syahrizal Halim, Department of Conservative Dentistry, School of Dental Sciences, Universiti Sains Malaysia Health Campus, 16150 Kota Bharu, Kelantan, Malaysia. E-mail: drsyah@usm.my

This is an open access journal, and articles are distributed under the terms of the Creative Commons Attribution-NonCommercial-ShareAlike 4.0 License, which allows others to remix, tweak, and build upon the work non-commercially, as long as appropriate credit is given and the new creations are licensed under the identical terms.

For reprints contact: reprints@medknow.com

How to cite this article: Singh JK, Sengut M, Halim MS, Ab-Ghani Z, Rahman NA. Safety comparison of over the counter bleaching with professionally prescribed home bleaching agent. Eur J Gen Dent 2018;7:35-40. 
The efficacy of bleaching agent can be determined clinically by measuring the color change of the tooth after the bleaching regimen. ${ }^{[10]}$ A change in tooth color after completing the bleaching regimen was reported with all methods of tooth bleaching. ${ }^{[11]}$ Pinto et al. reported that, after completing the bleaching regimen, all bleaching agents promoted a reduction in enamel microhardness and an increase in surface roughness. ${ }^{[12]}$ Although tooth bleaching does not create macroscopically visible defects, microscopic alterations could eventually cause undesirable effects. ${ }^{[13]}$ Rough surfaces manifested from tooth bleaching may predispose that area to extrinsic staining, bacteria adhesion, plaque maturation, and periodontal disease which may lead to even serious problem as a consequence. ${ }^{[14]}$

As a comparison to both methods of tooth bleaching, professional-prescribed home bleaching method has been found to be more superior in terms of color changes with OTC bleaching method. ${ }^{[15]}$ Another report found that professional-prescribed home bleaching method was the most effective method of tooth bleaching. ${ }^{[11]}$

Due to a limited study done on the comparison between color changes, enamel microhardness, and surface roughness, therefore, this study would like to compare the efficacy of professional home bleaching agent and OTC bleaching agent in bleaching tooth stained with human blood. The findings of this study would help to increase the community's awareness with regard to the different tooth bleaching techniques available in dentistry and help them to choose the bleaching agent which is effective and caused only minimal harm to their dentition.

\section{Materials and Methods}

Fifty-seven sound human permanent maxillary central and lateral incisors were collected from Outpatient Dental Clinic Hospital Universiti Sains Malaysia (HUSM). The teeth were extracted from patients with periodontal problem. The patients were given explanation on the research procedure, and their teeth will be discarded after the research. After the extraction, the tooth specimens were kept in thymol solution until sample preparation stage.

The tooth specimens were cleaned from debris with prophylaxis cup and pumice mounted on slow speed handpieces. Then, each tooth was embedded in self-curing clear acrylic resin (Vertex, The Netherlands) with labial surface of the tooth facing the mold base. ${ }^{[16]}$ Roots of the embedded teeth were cut and removed. The labial surface of the tooth was exposed by trimming off the excess acrylic using acrylic bur. The acrylic was flattened using the model trimmer to obtain even surface, and the size of specimen was standardized to $14 \mathrm{~mm} \times 8 \mathrm{~mm}( \pm 1 \mathrm{~mm}) \cdot{ }^{[16]}$ Then, samples were trimmed again to $2.6 \mathrm{~mm}$ thickness and were polished using sandpaper of decreasing grits of 500, 2500, and $5000 \mu \mathrm{m}$ (WS-FLEX 18, HERMES) providing finished section of $2.5 \mathrm{~mm}$ thickness and $14 \mathrm{~mm} \times 8 \mathrm{~mm}$ area.

Tooth specimens (2.5 $\mathrm{mm}$ thickness and $14 \mathrm{~mm} \times 8 \mathrm{~mm}$ area) were labeled then were divided randomly into three groups of 19. Baseline measurement for color, surface microhardness, and surface roughness were taken before staining procedure was done.

The samples were stained with human blood using slight modification from that of the technique introduced by Freccia and Peters. ${ }^{[17]}$ Enamel of the tooth was first etched to remove smear layer using 37\% phosphoric acid (SL Etchant Gel, SwissTEC) for $15 \mathrm{~s}$ and was rinsed using copious water. ${ }^{[16]}$ Thirty milliliters of human blood obtained from HUSM blood bank was filled into each centrifuging tube and was centrifuged at $5000 \mathrm{rpm}$ for $10 \mathrm{~min}$. Then, the blood plasma was removed from centrifuging tubes and distilled water was added until total volume reaches $35 \mathrm{ml}$. Blood was centrifuged again at $5000 \mathrm{rpm}$ for $10 \mathrm{~min}$ resulting in rich-hemoglobin hemolysate blood solution. Samples were left in the centrifuging tube for $24 \mathrm{~h}$. All the tubes were then centrifuged at $5000 \mathrm{rpm}$ for $20 \mathrm{~min}$, once a day, for 4 consecutive days with $24 \mathrm{~h}$ interval. After completing the cycles, samples were rinsed using distilled water. All samples were kept in $100 \%$ relative humidity at $37^{\circ} \mathrm{C}$ for 7 days before color measurement procedure. ${ }^{[16]}$

Table 1 shows the bleaching agent's manufacturer, composition, bleaching regimens used, and pattern number. The control group was kept in $100 \%$ relative humidity at $37^{\circ} \mathrm{C}$ for 10 days. For PB group, Opalescence PF 15\% Mint was applied about $1 \mathrm{~mm}$ thickness on the labial surface of the tooth samples using microbrush. Then, samples will be kept in $100 \%$ relative humidity at $37^{\circ} \mathrm{C}$ before rinsing it thoroughly with distilled water 4-6 h later. For WL group, the tooth whitening gels were applied about $1 \mathrm{~mm}$ thickness on the labial surface of the tooth sample. After that, the tooth will be exposed to light transmitter (simple light-emitting diode light provided by the manufacturer) for $10 \mathrm{~min}$ each. There is no manufacturer instruction on how many days this product

\begin{tabular}{|c|c|c|c|c|c|}
\hline Group & Bleaching agent & $\begin{array}{l}\text { Active } \\
\text { ingredient }\end{array}$ & Other ingredients & Regimens & $\begin{array}{l}\text { Patent } \\
\text { number }\end{array}$ \\
\hline 1 & $\begin{array}{l}\text { Opalescence PF } 15 \% \text { Mint } \\
\text { (Ultradent Products Inc., } \\
\text { South Jordan, USA) (PB) }\end{array}$ & $\begin{array}{l}15 \% \text { carbamide } \\
\text { peroxide }\end{array}$ & $\begin{array}{l}\text { Glycerin, Water, Xylitol, Carbomer, PEG-300, } \\
\text { Sodium Hydroxide, EDTA, Potassium Nitrate, } \\
\text { Sodium Fluoride }\end{array}$ & $\begin{array}{l}1 \text { daily application }(4-6 \mathrm{~h}) \\
\text { for } 10 \text { days }\end{array}$ & 89494.5 \\
\hline 2 & $\begin{array}{l}\text { The WhiteLight }{ }^{\mathrm{TM}} \\
\text { System (USA) (WL) }\end{array}$ & $\begin{array}{l}\text { Carbamide } \\
\text { peroxide }\end{array}$ & $\begin{array}{l}\text { Glycerin, Water, Povidone, Silica, Sodium } \\
\text { Hydroxide, Sodium Saccharin, K12.Sorbitol.EDTA }\end{array}$ & $\begin{array}{l}1 \text { daily application ( } 10 \mathrm{~min} \\
\text { with light transmitter) }\end{array}$ & 03364755.0 \\
\hline
\end{tabular}


must be used. However, cycle was repeated daily for 10 days for standardization purpose. After completing every cycle of bleaching, tooth samples were kept again in $100 \%$ relative humidity at $37^{\circ} \mathrm{C}$.

Shade of the tooth samples was measured using a digital spectrophotometer VITA Easyshade Advance 4.0 (VITA Zahnfabrik H. Rauter GmbH and Co. KG, Germany) before staining, after staining, and after bleaching procedure. Before color measurement, the samples were rinsed with distilled water and were dried using absorbent tissue. Samples were placed on a white paper during measurement to avoid disturbance in spectrophotometer reading from surrounding. The instrument was used to measure only at the central area of the tooth sample for basic shade measurement. The probe tip was placed perpendicular and in contact with the tooth surface. While holding the probe tip steadily against the enamel tooth surface, measurement button and the probe tip were held against the tooth until two rapid "beeps" heard that indicate the completion of the measurement. Then, the results displayed were recorded. The measurement will record $L^{*}, a^{*}, b^{*}$, where $L^{*}$ stands for luminosity dimensions or whiteness, ranging from 0 (pure black) to 100 (reference white), $a^{*}$ for green-red contrast $\left(-a^{*}=\right.$ green and $+a^{*}=$ red), and $b^{*}$ for blue-yellow contrast $\left(-b^{*}=\right.$ blue and $+b^{*}$ $=$ yellow). Color change $(\Delta \mathrm{E})$ was calculated using formula: $\Delta \mathrm{E}=\left(\left[\Delta \mathrm{L}^{*}\right]^{2}+\left[\Delta \mathrm{a}^{*}\right]^{2}+\left[\Delta \mathrm{b}^{*}\right]^{2}\right)^{1 / 2}$. Positive $\Delta \mathrm{L}^{*}$ means the samples became whiter, whereas negative $\Delta \mathrm{L}^{*}$ means samples became darker. ${ }^{[18]}$

Microhardness testing of the enamel was done before and after bleaching using Vickers hardness tester (VM 50; Fuel Instruments and Engineers Pvt. Ltd., Maharashtra, India). Each sample was observed through fitted microscope $(\times 10)$ for selecting the indentation area by placing it on the test base. The Vickers hardness indenter was set with $10 \mathrm{~kg}$ load for $20 \mathrm{~s}$. Three indentations were made for each sample before and after application of bleaching agent, and the readings were recorded. Average value of the samples microhardness was calculated.

Surface roughness measurement was done using a profilometer (Surfcom Flex-50A, Tokyo Seimitsu Co., Ltd., Japan) as baseline measurement and after bleaching application. This profilometer has measuring a range of $\pm 400 \mu \mathrm{m}$ for Z-axis direction, $50 \mathrm{~mm}$ for $X$-axis direction, with measuring resolution of $0.00016 \mu \mathrm{m} / \pm 4$ $\mu \mathrm{m}$ and $0.016 \mu \mathrm{m} / \pm 400 \mu \mathrm{m}$. The measuring speed available in four different speeds that is $0.15,0.3,0.6$, and $1.5 \mathrm{~mm} / \mathrm{s}$. In this study, we used speed of $0.15 \mathrm{~mm} / \mathrm{s}$ and evaluation length of $2 \mathrm{~mm}$. Three different readings were taken for each specimen. Average measurement readings were then calculated. ${ }^{[12]}$

\section{RESULTS}

Three groups of samples completed the study, namely, control (C), sample bleached with Opalescence PF 15\% (PB),

\begin{tabular}{|c|c|c|c|c|c|c|}
\hline Group & Variables & $\begin{array}{l}\text { Pre-staining } \\
\text { mean (SD) }\end{array}$ & $\begin{array}{c}\text { Post-staining } \\
\text { mean (SD) }\end{array}$ & $\begin{array}{l}\text { Mean difference } \\
(95 \% \mathrm{CI})\end{array}$ & $\begin{array}{l}t \text {-statistics } \\
\text { (df) }^{\mathrm{a}}\end{array}$ & $P$ \\
\hline \multirow[t]{3}{*}{ Control } & L value & $89.9(5.28)$ & $63.6(7.13)$ & $26.4(22.73,29.99)$ & $15.25(18)$ & $<0.001$ \\
\hline & a value & $-0.1(3.00)^{\mathrm{b}}$ & $0.7(4.77)^{\mathrm{b}}$ & - & - & $0.763^{c}$ \\
\hline & $\mathrm{b}$ value & $31.5(6.13)$ & $21.0(4.50)$ & $10.5(8.12,12.80)$ & $9.36(18)$ & $<0.001$ \\
\hline \multirow{3}{*}{$\begin{array}{l}\text { Opalescence PF } \\
15 \%(\mathrm{~PB})\end{array}$} & $\mathrm{L}$ value & $87.8(4.92)$ & $64.4(4.71)$ & $23.4(19.98,26.73)$ & $14.55(18)$ & $<0.001$ \\
\hline & a value & $0.5(2.50)^{b}$ & $-0.4(2.37)^{b}$ & - & - & $0.198^{\mathrm{c}}$ \\
\hline & $\mathrm{b}$ value & $30.4(6.43)$ & $21.7(4.06)$ & $8.8(6.49,11.05)$ & $8.07(18)$ & $<0.001$ \\
\hline \multirow{3}{*}{$\begin{array}{l}\text { White light Tooth } \\
\text { Whitening (WL) }\end{array}$} & $\mathrm{L}$ value & $89.7(4.27)$ & $66.5(2.80)$ & $23.2(20.77,25.59)$ & $20.23(18)$ & $<0.001$ \\
\hline & a value & $0.3(1.80)^{b}$ & $-0.8(2.37)^{\mathrm{b}}$ & - & - & $0.091^{\mathrm{c}}$ \\
\hline & $\mathrm{b}$ value & $32.2(6.06)$ & $20.9(4.45)$ & $11.3(9.30,13.30)$ & $11.89(18)$ & $<0.001$ \\
\hline
\end{tabular}

${ }^{\mathrm{a} P a i r e d} t$-test, ${ }^{\mathrm{b}}$ Median (IQR), ${ }^{\mathrm{c}}$ Wilcoxon Signed Rank Test (Z-statistics)

\begin{tabular}{|c|c|c|c|c|c|c|}
\hline Group & Variables & $\begin{array}{l}\text { Post-staining } \\
\text { Mean (SD) }\end{array}$ & $\begin{array}{l}\text { Post-bleaching } \\
\text { Mean (SD) }\end{array}$ & $\begin{array}{l}\text { Mean difference } \\
(95 \% \mathrm{CI})\end{array}$ & $\begin{array}{c}t \text {-statistics } \\
\text { (df) }^{\mathrm{a}}\end{array}$ & $P$ \\
\hline \multirow[t]{3}{*}{ Control } & L value & $63.6(7.13)$ & $63.6(7.13)$ & - & - & - \\
\hline & a value & $0.7(4.77)^{\mathrm{b}}$ & $0.7(4.77)^{\mathrm{b}}$ & - & - & - \\
\hline & $\mathrm{b}$ value & $21.0(4.50)$ & $21.0(4.50)$ & - & - & - \\
\hline \multirow{3}{*}{$\begin{array}{l}\text { Opalescence PF } \\
15 \%(\mathrm{~PB})\end{array}$} & $\mathrm{L}$ value & $64.4(4.71)$ & $75.6(4.98)$ & $-11.1(-13.28,-8.96)$ & $-10.82(18)$ & $<0.001$ \\
\hline & a value & $-0.4(2.37)^{\mathrm{b}}$ & $-0.8(1.37)^{\mathrm{b}}$ & - & - & $0.025^{\mathrm{c}}$ \\
\hline & $\mathrm{b}$ value & $21.7(4.06)$ & $18.0(4.68)$ & $3.7(2.43,4.96)$ & $6.14(18)$ & $<0.001$ \\
\hline \multirow{3}{*}{$\begin{array}{l}\text { Whitelight Tooth } \\
\text { Whitening (WL) }\end{array}$} & $\mathrm{L}$ value & $66.5(2.80)$ & $77.7(5.69)$ & $-11.2(-13.18,-9.18)$ & $-11.75(18)$ & $<0.001$ \\
\hline & a value & $-0.8(2.37)^{\mathrm{b}}$ & $-0.6(1.40)^{\mathrm{b}}$ & - & - & $0.856^{\mathrm{c}}$ \\
\hline & $\mathrm{b}$ value & $20.9(4.45)$ & $24.7(5.14)$ & $-3.8(-5.33,-2.19)$ & $-5.05(18)$ & $<0.001$ \\
\hline
\end{tabular}

${ }^{a}$ Paired $t$-test, ${ }^{b}$ Median (IQR), ${ }^{c}$ Wilcoxon Signed Rank Test (Z-statistics) 
and sample bleached with Whitelight Tooth Whitening set (WL).

Table 2 displays the mean (standard deviation [SD]) values or median (interquartile range) of $\mathrm{L}^{*}, \mathrm{a}^{*}$, and $\mathrm{b}^{*}$ values obtained from the colorimetric measurement for all groups for pre- and poststaining with human blood. The $\mathrm{L}^{*}, \mathrm{a}^{*}$, and $\mathrm{b}^{*}$ values did not show any significant difference between the groups, showing the samples were properly randomized. For all groups, there was a significant change in $\mathrm{L}^{*}$ and $\mathrm{b}^{*}$ values $(P<0.001)$ after staining the samples but not for the $\mathrm{a}^{*}$ value.

Table 3 shows the mean (SD) values of $L^{*}, a^{*}$, and $b^{*}$ values obtained from the colorimetric measurement for all groups for prebleaching (poststaining) and postbleaching. PB group shows significant difference for $\mathrm{L}^{*}$ value, $\mathrm{b}^{*}$ value $(P<0.001)$, and $\mathrm{a}^{*}$ value $(P=0.025)$. $\mathrm{L}^{*}$ value for $\mathrm{PB}$ group increased by 11.1 , while the $b^{*}$ value decreased by 3.7 after bleaching regimen. For the WL group, only $\mathrm{L}^{*}$ and $\mathrm{b}^{*}$ value showed $\mathrm{a}$ significant difference $(P<0.001)$, while changes for $a^{*}$ value were not significant. $\mathrm{L}^{*}$ value for WL group increased by 11.2, while $b^{*}$ value increased by 3.8 .

Table 4 shows the mean color changes $(\Delta \mathrm{E})$, the difference in microhardness, and the difference in surface roughness after completing the bleaching regimen. PB group and WL group both recorded a color change with a mean of 12.2 after bleaching, respectively. PB group showed a significant difference of microhardness after bleaching $(P<0.001)$ and an increment of the microhardness by 143.1. On the other hand, WL also showed a significant difference with an increment of $109.6(P=0.001)$. For surface roughness measurement, both PB group and WL group did not show any significant difference in surface roughness after bleaching $(P=0.389$ and $P=0.491$, respectively).

Table 5 summarizes the changes in test parameters for the two experimental groups. For color changes after bleaching, two pairs of group have significant difference after bleaching which is control-PB group and control-WL group $(P<0.001)$. However, there is no significant difference for the pair PB-WL. As for the difference in microhardness, two pairs of group have significant difference after bleaching which is control-PB group $(P<0.001)$ and control-WL group $(P=0.001)$. There is no significant difference for the pair PB-WL. There was no significant difference noticed between the groups for difference in surface roughness after bleaching $(P=0.733)$.

\section{Discussion}

This study was carried out to determine the efficacy and effect of professional home bleaching agent and OTC bleaching agent on human natural tooth by measuring color changes, difference in microhardness, and difference in surface roughness.

It is difficult to observe the color changes on samples in bleaching assessment without staining it. Thus, in this study, we used the staining technique from study conducted by Freccia and Peter in 1982. ${ }^{[17]}$ According to this method, it is believed that the intrinsic tooth discoloration was due to the oxidation of hemoglobin inside dentinal tubules. After centrifuge, the blood was separated into two distinct phases: a continuous, liquid, yellowish phase called plasma, and a discontinuous, red, dense phase represented by the blood cells, thus containing

\begin{tabular}{|c|c|c|c|c|c|c|}
\hline Group & $\begin{array}{l}\text { Assessment } \\
\text { Parameters }\end{array}$ & $\begin{array}{l}\text { Pre-bleaching } \\
\text { Mean (SD) }\end{array}$ & $\begin{array}{l}\text { Post-bleaching } \\
\text { Mean (SD) }\end{array}$ & $\begin{array}{l}\text { Mean difference } \\
\quad(95 \% \mathrm{Cl})\end{array}$ & $\begin{array}{l}t \text {-statistics } \\
(\mathrm{d} f)^{\mathrm{a}}\end{array}$ & $P$ \\
\hline \multirow{3}{*}{$\begin{array}{l}\text { Opalescence PF } \\
15 \%(\mathrm{~PB})\end{array}$} & Colour changes & $25.6(6.24)$ & $12.2(4.07)$ & 13.40 & $9.267(18)$ & 0.000 \\
\hline & Microhardness & $357.3(57.04)$ & $500.4(121.10)$ & $-143.1(208.22,-78.10)$ & $-4.63(18)$ & $<0.001$ \\
\hline & Surface roughness & $0.5(0.14)$ & $0.5(0.11)$ & $0.0(-0.03,0.07)$ & $0.88(18)$ & 0.389 \\
\hline \multirow{3}{*}{$\begin{array}{l}\text { Whitelight tooth } \\
\text { whitening (WL) }\end{array}$} & Colour changes & $26.3(4.28)$ & $12.2(4.32)$ & 14.04 & $-4.182(18)$ & 0.000 \\
\hline & Microhardness & $361.4(41.75)$ & $471.0(114.47)$ & $-109.6(-164.68,-54.55)$ & $-4.18(18)$ & 0.001 \\
\hline & Surface roughness & $0.5(0.11)$ & $0.5(0.10)$ & $0.0(-0.03,0.05)$ & $0.70(18)$ & 0.491 \\
\hline
\end{tabular}

aaired $t$-test

Table 5: Comparisons between groups after bleaching regime

\begin{tabular}{|c|c|c|c|c|c|}
\hline Variables & Groups & $n$ & Mean (SD) & F Statistics (df)a & $P$ \\
\hline \multirow{2}{*}{$\begin{array}{l}\text { Colour change } \\
\text { after bleaching }\end{array}$} & Opalescence PF $15 \%$ (PB) & 19 & $12.2(4.07)$ & $80.657(2)$ & $<0.001^{\mathrm{c}}$ \\
\hline & Whitelight Tooth Whitening (WL) & 19 & $12.2(4.32)$ & & \\
\hline \multirow{2}{*}{$\begin{array}{l}\text { Difference in } \\
\text { microhardness }\end{array}$} & Opalescence PF $15 \%(\mathrm{~PB})$ & 19 & $124.7(200.00)^{\mathrm{b}}$ & - & $<0.001^{\mathrm{d}, \mathrm{e}}$ \\
\hline & Whitelight Tooth Whitening (WL) & 19 & $88.7(174.67)^{b}$ & & \\
\hline \multirow{2}{*}{$\begin{array}{l}\text { Difference in } \\
\text { surface roughness }\end{array}$} & Opalescence PF 15\% (PB) & 19 & $0.0(0.18) \mathrm{b}$ & - & $0.733^{\mathrm{d}}$ \\
\hline & Whitelight Tooth Whitening (WL) & 19 & $0.0(0.06) \mathrm{b}$ & & \\
\hline
\end{tabular}

${ }^{a}$ ANOVA, ${ }^{b}$ Median (IQR), ${ }^{\text {CT }}$ wo pair of groups have statistically significant difference by Post-hoc Scheffe Test: Control- Opalescence PF $15 \%$ ( $\left.P<0.001\right)$ and Control- Whitelight Tooth Whitening $(P<0.001)$. ${ }^{d}$ Kruskal-Wallis Test ( $H$-statistics). ${ }^{e}$ Two pair of groups have statistically significant difference by Mann-Whitney Test: Control- Opalescence PF 15\% $(P<0.001)$ and Control- Whitelight Tooth Whitening $(P=0.001)$ 
hemoglobin. Red blood cells and hemoglobin pigments penetrate into the tooth structures to give more discriminative contrast in evaluation of superficial and in-depth action after application of different bleaching agents. ${ }^{[1]}$ After blood staining procedure on the tooth samples, the colorimetric analysis showed that $\mathrm{L}^{*}$ and $\mathrm{b}^{*}$ values decreased, while $\mathrm{a}^{*}$ value has no significant changes in all groups. The decrease in $\mathrm{L}^{*}$ value for all groups shows that the sample became darker; meanwhile, the decrease in $b^{*}$ value shows that the yellowness of the sample is reduced compared to prestaining. This indicates that the samples were uniform and even result of staining was achieved to start with the bleaching regimen.

After bleaching, the $\mathrm{L}^{*}$ value for $\mathrm{PB}$ and WL groups increased showing that the tooth became lighter. However, the $\mathrm{b}^{*}$ value for PB group decreased, while WL group recorded an increase in $b^{*}$ value. This shows that the yellowness in PB group decreased, while for WL group, the yellowness of the tooth sample increased. The $\mathrm{a}^{*}$ value for PB group decreased significantly showing that the bleaching agent worked to reduce the redness of the tooth sample. Although both bleaching agents recorded the same mean color changes of 12.2 after bleaching, the efficacy of $\mathrm{PB} \%$ was slightly more apparent compared to WL as it not only managed to lighten the tooth, but also it reduced the yellowness and redness of the tooth sample, but statistically, both have the same efficacy compared to the control group and there is no statistical significance between the two groups.

This study revealed a significant increase in microhardness of tooth sample for both PB and WL groups after bleaching with $\mathrm{PB}$ group showing higher increment. However, these results contradict the study done by Lopes et al. that shows no alterations on enamel surface after application of $10 \%$ carbamide peroxide gel (Opalescence) ${ }^{[19]}$ Study by Delfino et al. also revealed no changes in microhardness of bovine enamel after bleaching with $10 \%$ carbamide peroxide gel, $16 \%$ carbamide peroxide gel, and $6.5 \%$ hydrogen peroxide-based strips. ${ }^{[20]}$ Microstructural alterations in bleached enamel may be reversed by the remineralization action of fluoride that is contained in the PB group (Opalescence PF 15\%) which also further strengthens enamel. However, the increase in microhardness for WL group needs further investigation of whether or not it contains fluoride which has not been mentioned by the manufacturer.

None of the groups in this study showed the statistically significant difference for surface roughness after bleaching. However, the study conducted by Pinto et al. that used whiteness perfect $10 \%$ carbamide peroxide $(10 \% \mathrm{CP})$, Colgate Platinum (10\% CP), Day White 2Z (7.5\% HP), Whiteness Super (35\% CP), Opalescence Quick (35\% CP), and Whiteness HP (35\% HP) show that all groups increased in surface roughness $(P<0.05) \cdot{ }^{[12]}$ Pinto in his study used profilometer Surf-Corder SE 1200 (Kosaka Lab Ltd., Tokyo, Japan) with a measuring range of $520 \mu \mathrm{m}$ vertically, $25 \mathrm{~mm}$ horizontally, vertical resolution of $0.008 \mu \mathrm{m}$, and measuring speed of
0.2 and $0.5 \mathrm{~mm} / \mathrm{s}$. The profilometer used in our study has a wider measuring range and speed; thus, it is more sensitive compared to the profilometer used by Pinto in his study. This shows that the minimal and nonsignificant changes of surface roughness observed in this study are legit.

This is an in vitro study, so the results obtained may subject to some differences as compared to in vivo studies due to the absence of clinical variables such as salivary components, oral cavity temperature, $\mathrm{pH}$, continuous cyclic fatigue, and patient's diet.

\section{Conclusions}

With all the limitations in this study, it can be concluded that professional home bleaching agent showed similar efficacy, with no effect on surface roughness, and both caused an increment in microhardness. The changes observed for the microhardness of tooth sample after bleaching regimen in this study warrants additional investigation.

\section{Acknowledgment}

Mr. Mohd Yusoff Soon Abdullah, Mrs. Nora Aziz, Mr. Mohd Saiful Bahrin Mat Nasir, Mr. Fairuz Hasbullah, Mr. Mohamad Zulhelmi Mohd Nor from School of Dental Sciences, USM.

\section{Financial support and sponsorship}

This study was financially supported by USM Short Term Grant: 304/PPSG/61313102.

\section{Conflicts of interest}

There are no conflicts of interest.

\section{REFERENCES}

1. Addy M, Moran J, Newcombe R, Warren P. The comparative tea staining potential of phenolic, chlorhexidine and anti-adhesive mouthrinses. J Clin Periodontol 1995;22:923-8.

2. Neumann LM, Christensen C, Cavanaugh C. Dental esthetic satisfaction in adults. J Am Dent Assoc 1989;118:565-70.

3. Attin T, Betke H, Schippan F, Wiegand A. Potential of fluoridated carbamide peroxide gels to support post-bleaching enamel re-hardening. J Dent 2007;35:755-9.

4. Haywood VB, Heymann HO. Nightguard vital bleaching: How safe is it? Quintessence Int 1991;22:515-23.

5. Haywood VB, Heymann HO. Nightguard vital bleaching. Quintessence Int 1989;20:173-6.

6. Haywood VB, Leech T, Heymann HO, Crumpler D, Bruggers K. Nightguard vital bleaching: Effects on enamel surface texture and diffusion. Quintessence Int 1990;21:801-4.

7. Kihn PW. Vital tooth whitening. Dent Clin North Am 2007;51:319-31, viii.

8. Hattab FN, Qudeimat MA, al-Rimawi HS. Dental discoloration: An overview. J Esthet Dent 1999;11:291-310.

9. Demarco FF, Meireles SS, Masotti AS. Over-the-counter whitening agents: A concise review. Braz Oral Res 2009;23 Suppl 1:64-70.

10. van der Burgt TP, ten Bosch JJ, Borsboom PC, Kortsmit WJ. A comparison of new and conventional methods for quantification of tooth color. J Prosthet Dent 1990;63:155-62.

11. Matis BA, Cochran MA, Eckert G. Review of the effectiveness of various tooth whitening systems. Oper Dent 2009;34:230-5.

12. Pinto CF, Oliveira Rd, Cavalli V, Giannini M. Peroxide bleaching agent effects on enamel surface microhardness, roughness and morphology. Braz Oral Res 2004;18:306-11. 
13. Ernst CP, Marroquín BB, Willershausen-Zönnchen B. Effects of hydrogen peroxide-containing bleaching agents on the morphology of human enamel. Quintessence Int 1996;27:53-6.

14. Cavalli V, Arrais CA, Giannini M, Ambrosano GM. High-concentrated carbamide peroxide bleaching agents effects on enamel surface. J Oral Rehabil 2004;31:155-9.

15. Bizhang M, Chun YH, Damerau K, Singh P, Raab WH, Zimmer S, et al. Comparative clinical study of the effectiveness of three different bleaching methods. Oper Dent 2009;34:635-41.

16. Dietschi D, Rossier S, Krejci I. In vitro colorimetric evaluation of the efficacy of various bleaching methods and products. Quintessence Int 2006;37:515-26.

17. Freccia WF, Peters DD. A technique for staining extracted teeth:
A research and teaching aid for bleaching. J Endod 1982;8:67-9.

18. Delfino CS, Chinelatti MA, Carrasco-Guerisoli LD, Batista AR, Fröner IC, Palma-Dibb RG, et al. Effectiveness of home bleaching agents in discolored teeth and influence on enamel microhardness. J Appl Oral Sci 2009; 17:284-8.

19. Lopes GC, Bonissoni L, Baratieri LN, Vieira LC, MONTEIRO S. Effect of bleaching agents on the hardness and morphology of enamel. Journal of Esthetic and Restorative Dentistry. 2002 Jan 1;14:24-30.

20. Hannig C, Zech R, Henze E, Dorr-Tolui R, Attin T. Determination of peroxides in saliva - Kinetics of peroxide release into saliva during home-bleaching with whitestrips and vivastyle. Arch Oral Biol 2003;48:559-66

\section{Author Help: Online submission of the manuscripts}

Articles can be submitted online from http://www.journalonweb.com. For online submission, the articles should be prepared in two files (first page file and article file). Images should be submitted separately.

1) First Page File:

Prepare the title page, covering letter, acknowledgement etc. using a word processor program. All information related to your identity should be included here. Use text/rtf/doc/pdf files. Do not zip the files.

\section{2) Article File:}

The main text of the article, beginning with the Abstract to References (including tables) should be in this file. Do not include any information (such as acknowledgement, your names in page headers etc.) in this file. Use text/rtf/doc/pdf files. Do not zip the files. Limit the file size to 1 MB. Do not incorporate images in the file. If file size is large, graphs can be submitted separately as images, without their being incorporated in the article file. This will reduce the size of the file.

3) Images:

Submit good quality color images. Each image should be less than $4096 \mathrm{~kb}(4 \mathrm{MB})$ in size. The size of the image can be reduced by decreasing the actual height and width of the images (keep up to about 6 inches and up to about $1800 \times 1200$ pixels). JPEG is the most suitable file format. The image quality should be good enough to judge the scientific value of the image. For the purpose of printing, always retain a good quality, high resolution image. This high resolution image should be sent to the editorial office at the time of sending a revised article.

4) Legends:

Legends for the figures/images should be included at the end of the article file. 
ISSN 2278-9626

Volume 7 / Issue 2 / May-August 2018

\section{European Journal of \\ General Dentistry}

Official Publication of Ishik University School of Dentistry www.ejgd.org 